\title{
Annual and Seasonal Changes in Zooplankton Community Structure of Lake Kawaguchi, Japan
}

\author{
Takashi ARakawa, Norihiko Yoshida, Kazuya Yoshizawa \\ and Kimio HiraBaYASHI
}

\begin{abstract}
Annual and seasonal changes in the community structure of metazoan plankton in Lake Kawaguchi were studied from April 1993 to December 1995. Sixteen taxa of rotifer, 4 taxa of cladoceran and 5 taxa of copepods were identified in this study. Among zooplankton species, Kellicottia longispina, Synchaeta stylata, Bosmina longirostris, and Daphnia galeata were found abundantly. Copepod species were grouped into Cyclopoida. A comparison of the present with previous studies indicates that some cladoceran species, Bosmina fatalis and Bosminopsis deitersi, have vanished altogether. It may be concluded that the structure of the zooplankton community in this lake has changed remarkably in recent years.
\end{abstract}

Key words : zooplankton, community structure, seasonal changes, annual changes, Lake Kawaguchi

\section{INTRODUCTION}

Lake Kawaguchi is a volcanic dammed lake located at the northern foot of Mt. Fuji $\left(35^{\circ} 31^{\prime} \mathrm{N}, 138^{\circ} 45^{\prime} \mathrm{E}\right)$. The surface area of this lake is $5.96 \mathrm{~km}^{2}$, the mean depth $9.3 \mathrm{~m}$, maximum depth $16.1 \mathrm{~m}$ and the surface elevation $832 \mathrm{~m}$ above sea level. The lake is elongated in shape along an axis from east to west, and has three basins (the western, eastern and Funatsu basin) divided by Unoshima island and the Fujinokihana lake ridge (Fig. 1).

A number of studies have examined the limnological condition of this lake (TANAKA, 1992), some of which have mentioned the long-term change in water quality (IWAO, 1971; SHIMIzU et al., 1990). These studies have reported that eutrophication in this lake had worsened up to the 1970 s, but that water quality was restored by the 1980s. TAKAHASHI et al. (1995) reported that the standing crop of planktivorus pond smelt (Hypomesus transpacificus nipponensis) has decreased in recent years. It is well known that planktivorus fish strongly affect the zooplankton community (BROOKS and DoDson, 1965).

Therefore, the zooplankton community may have changed in recent years due to changes in water quality and fish fauna. Several studies have examined the zooplankton community structure in Lake Kawaguchi (INABA, 

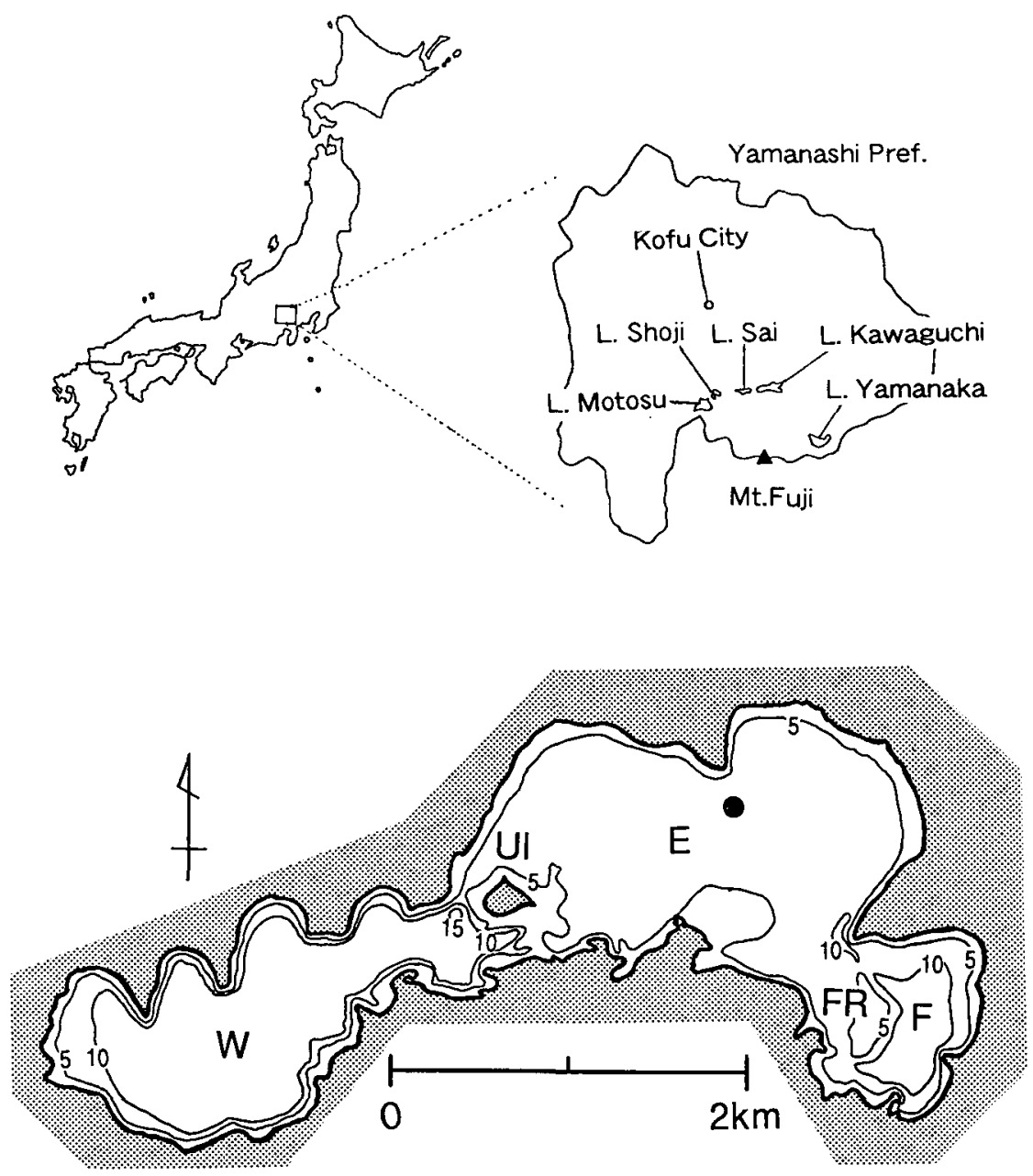

Fig. 1. Map of Lake Kawaguchi. Solid circle : sampling point, $\mathrm{W}$ : western basin, $\mathrm{E}$ : eastern basin, F : Funatsu basin, UI : Unoshima island, FR : Fujinokihana ridge.

1934 ; Kadota, 1962 ; InaO, 1971 ; Furuta et al., 1974 ; TaNaka, 1992). However, the information on fauna and seasonal changes in the population densities of zooplankton species is very limited. The purpose of this study is to examine whether the community structure of metazoan plankton has changed recent years in Lake Kawaguchi. For this, we investigated zooplankton monthly for 3 years, and did a comparison of zooplankton fauna between the present and the previous studies.

\section{METHODS}

The measurement of abiotic factors and water sampling were carried out 
monthly at a fixed point (9.5 m max. depth) of the eastern basin (Fig. 1) from April 1993 to December 1995. Water transparency was determined with a secchi disc. Water temperature and dissolved oxygen concentration were vertically measured with a thermistor thermometer and an electrode (YSI, MODEL58) at $1 \mathrm{~m}$ intervals from surface to bottom. Lake water was collected with a Van-Dorn sampler (5l) from depths of 0,2,6 and $9 \mathrm{~m}$ (or bottom when the bottom depth was $<9 \mathrm{~m}$ ) for the measurement of chlorophyll $a$ concentration (UNESCO, 1966) .

Zooplankton samples were collected by vertical tows with a Marukawatype net (net opening $30 \mathrm{~cm}$ diameter, mesh opening $94 \mu \mathrm{m}$ ) from 0 to $2 \mathrm{~m}$ (surface layer), from 2 to $6 \mathrm{~m}$ (middle layer) and from 6 to $9 \mathrm{~m}$ (or $6 \mathrm{~m}$ to bottom, bottom layer) layers. Zooplankton were fixed immediately after the sampling with glutaraldehyde solution (final concentration $3 \%$ ), and were identified and counted at species level under a microscope except for copepods which were grouped into nauplius, copepodid and adult stages. During the study, protozoan species, Dinobryon spp. (cylindrica and divergens) were abundantly collected by the vertical tows commonly, so that their colony density was also estimated.

\section{RESULTS AND DISCUSSION}

Transparency fluctuated between $2.2 \mathrm{~m}$ (October 1994) and $7.9 \mathrm{~m}$ (July 1994) during the study period, with a tendency to be higher in summer and fall than in winter and spring (Fig. 2-a). The water temperature fluctuated between $26.8^{\circ} \mathrm{C}$ (August 1995, surface) and $2.1^{\circ} \mathrm{C}$ (February 1994, surface, Fig. 2-b). The thermocline developed at depths of about $4 \sim 6 \mathrm{~m}$ from June to September in 1993, and from April to September in 1994 and 1995. The summer water temperature was lower in $1993\left(\max .23 .0^{\circ} \mathrm{C}\right)$ than in the following two years $\left(\max .26 .4^{\circ} \mathrm{C}\right.$ in $1994,26.8^{\circ} \mathrm{C}$ in 1995$)$.

A low-oxygen layer $\left(<3 \mathrm{mg} \mathrm{O} \mathrm{O}_{2} \mathrm{l}^{-1}\right)$ developed near the bottom every summer (Fig. 2-c). Seasonal changes in dissolved oxygen concentration (DO) showed a different pattern between 1995 and other years. In 1993 and 1994, DO in the whole water column decreased with increasing water temperature in spring; and after the development of a low oxygen layer at the bottom, DO increased with decreasing water temperature in fall. On the other hand, in 1995, DO increased in spring and reached the maximum of over $10 \mathrm{mg} \mathrm{l}^{-1}$ in June and July in the layers from the surface to $3 \mathrm{~m}$ ( $\max$. $12.5 \mathrm{mg} \mathrm{l}^{-1}$ on June, surface) and decreased thereafter. A low-oxygen layer appeared at the bottom in June, and developed up to $6 \mathrm{~m}$ deep in August.

Chlorophyll $a$ (Chl. $a$ ) concentration reached over $20 \mu \mathrm{g} \mathrm{l}^{-1}$ at the surface and $2 \mathrm{~m}$ layers in summer 1995 (max. $30.7 \mu \mathrm{g} \mathrm{l} \mathrm{l}^{-1}$, June, surface, Fig. 2-d), because a dense bloom of the dinoflagellate, Peridinium sp. appeared (June and July, 1995). A high Chl. $a$ concentration found at the bottom in July and August 1994 (Fig. 2-d) is, however, due to a bloom of dinoflagellate Ceratium hirundinella (about 13,000 individuals $1^{-1}$ ). 

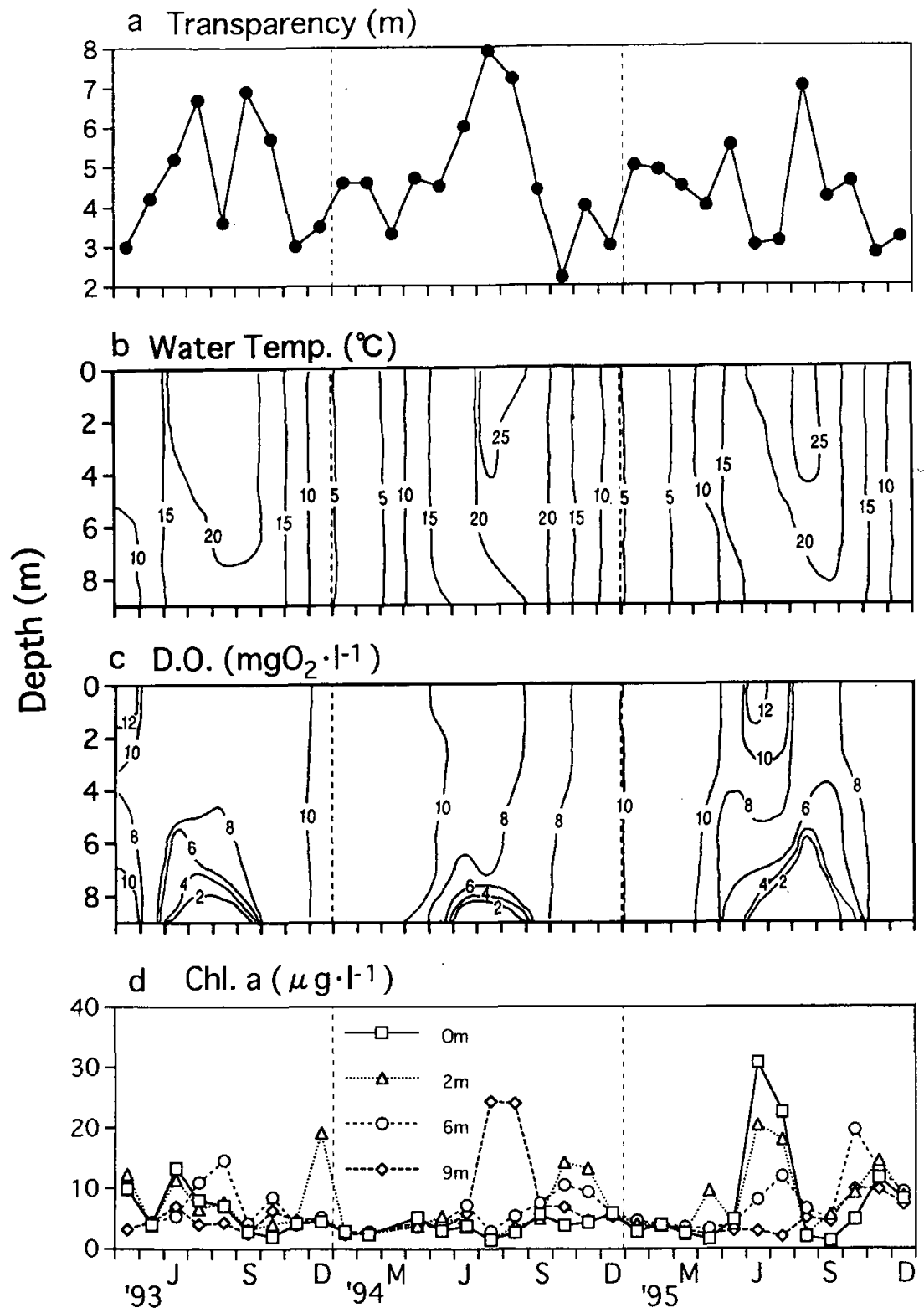

Fig. 2. Seasonal changes in transparency $(\mathrm{Tr} .)^{-\mathrm{a})}$ and chlorophyll $a$ concentration $(\text { Chl. } a)^{-d)}$. Seasonal and vertical distribution of isopleth of water temperature (Water Temp. $)^{-b}$, dissolved oxygen concentration (DO) ${ }^{-c)}$. Note : left axis $(m)$ in a) differ from in b) and c).

During the study period (total 33 sampling times, 9,12 and 12 times in 1993, 1994 and 1995, respectively), 25 taxa of metazoan plankton were identified (Table 1). Other metazoans, protozoans, Dinobryon cylindrica and $D$. divergens, were commonly collected in the spring.

Among rotifer species, Asplanchna priodonta, Kellicottia longispina, 
Table 1. A list of zooplankton species which appeared in eastern basin of Lake Kawaguchi with the number of dates when the species were sampled (the total number of sampling dates ; 9, 12 and 12 in 1993, 1994 and 1995, respectively), mean annual density and maximum density (individuals $1^{-1}$ ) in each year.

\begin{tabular}{|c|c|c|c|c|c|c|c|c|c|}
\hline \multirow[b]{2}{*}{ Taxa } & \multicolumn{3}{|c|}{1993} & \multicolumn{3}{|c|}{1994} & \multicolumn{3}{|c|}{1995} \\
\hline & $\begin{array}{l}\text { No. of } \\
\text { dates }\end{array}$ & $\begin{array}{c}\text { Mean } \\
\text { density }\end{array}$ & $\begin{array}{l}\text { Max. density } \\
\text { (month-layer) }\end{array}$ & $\begin{array}{l}\text { No. of } \\
\text { dates }\end{array}$ & $\begin{array}{c}\text { Mean } \\
\text { density }\end{array}$ & $\begin{array}{c}\text { Max. density } \\
\text { (month-layer) }\end{array}$ & $\begin{array}{l}\text { No. of } \\
\text { dates }\end{array}$ & $\begin{array}{l}\text { Mean } \\
\text { density }\end{array}$ & $\begin{array}{l}\text { Max. density } \\
\text { (month-layer) } \\
\end{array}$ \\
\hline \multicolumn{10}{|c|}{ C. } \\
\hline Asplanchna priodonta & 6 & 1.0 & 13.1 (Dec-B) & 6 & 1.7 & 13.3(Dec-S) & 5 & 0.3 & 6.2 (Oct-S) \\
\hline Collotheca sp. & 2 & $<0.1$ & $0.6($ Nov-S $)$ & 2 & $<0.1$ & 0.4 (Nov-S) & 4 & $<0.1$ & 0.5 (Nov-S) \\
\hline Conochilus unicornis & 0 & & & 2 & 1.5 & 46.4 (Aug-S) & 0 & & \\
\hline Diurella stylata & 0 & & & 2 & $<0.1$ & 0.2 (Oct-S) & 0 & & \\
\hline Hexarthra mira & 0 & & & 0 & & & 2 & $<0.1$ & 0.3 (Aug-S) \\
\hline Kellicottia longispina & 9 & 2.9 & 16.2 (Jul-B) & 7 & 9.7 & 124 (Apr-M) & 5 & 1.0 & 9.3(Apr-M) \\
\hline Keratella cochlearis & 2 & $<0.1$ & 0.6 (Apr-S) & 8 & 0.3 & 4.5 (Aug.B) & 7 & $<0.1$ & 1.1 (Feb-S) \\
\hline Ploesoma lenticulare & 1 & $<0.1$ & $0.4(\mathrm{Nov} \cdot \mathrm{S})$ & 2 & $<0.1$ & 0.4 (Oct.S) & 1 & $<0.1$ & 2.3 (Oct-S) \\
\hline Ploesoma truncatum & 7 & 0.7 & 5.1 (Nov-S) & 9 & 1.6 & 17.3 (Nov-S) & 6 & 0.6 & (Oct-S) \\
\hline Polyarthra e & 2 & 2.1 & 28.3 (Sep-S) & 2 & 0.1 & $2.4($ Oct-S $)$ & 5 & 0.8 & (Sep-S) \\
\hline Polyarthra & 4 & 0.1 & 1.1 (Nov-S) & 5 & $<0.1$ & $0.9($ Oct-S $)$ & 6 & 0.2 & (Jul-S) \\
\hline $\begin{array}{l}\text { Polyarthra spp. } \\
\text { P. dolichoptera } \\
\text { P. vulgaris }\end{array}$ & 8 & 0.4 & $3.4(\mathrm{Sep}-\mathrm{S})$ & 10 & 1.1 & $9.5($ Mar-S $)$ & 11 & 0.6 & $7.3($ Sep-S) \\
\hline Synchaeta oblonga & 2 & 0.1 & 3.2 (Sep-S) & 2 & $<0.1$ & 1.5 (Oct-S) & 1 & $<0.1$ & $0.2(\mathrm{Jun}-\mathrm{S})$ \\
\hline Synchaeta stylata & 6 & 0.2 & 1.1 (Oct-S) & 9 & 2.4 & 43.7 (Feb-M) & 9 & 0.4 & 2.6 (Aug-S) \\
\hline Trichocerca sp. & 1 & $<0.1$ & 0.4 (Aug.S) & 3 & $<0.1$ & 0.8 (Nov-B) & 2 & $<0.1$ & 0.4 (Nov-S) \\
\hline \multicolumn{10}{|l|}{ Cladocera } \\
\hline Bosmina longorostris & 3 & 0.8 & 10.5 (Dec-B) & 9 & 2.0 & $16.6(\mathrm{Jan} \cdot \mathrm{S})$ & 8 & 1.2 & 20.6 (Nov-S) \\
\hline Chydorus gibbus & 0 & & & 1 & $<0.1$ & $<0.1$ (Jun-B) & 5 & $<0.1$ & $0.2($ Jun-S $)$ \\
\hline Daphnia galeata & 8 & 2.4 & 13.5 (May-S) & 8 & 1.3 & 12.7 (Jun-S) & 9 & 0.8 & 7.4 (Aug-M) \\
\hline Leptodora kindtii & 1 & $<0.1$ & 0.1 (Aug-M) & 4 & $<0.1$ & 0.2 (May-B) & 1 & $<0.1$ & $0.2(\mathrm{Jun}-\mathrm{S})$ \\
\hline \multicolumn{10}{|l|}{ Copepoda } \\
\hline *Calanoida & 1 & $<0.1$ & 0.2 (May-M) & 0 & & & 0 & & \\
\hline Cyclopoida & 6 & 0.1 & 0.8 (Jul-B) & 2 & $<0.1$ & $1.0(\mathrm{Dec}-\mathrm{S})$ & 7 & $<0.1$ & 0.3 (Aug-B) \\
\hline \multirow{2}{*}{\multicolumn{10}{|c|}{$\begin{array}{l}\text { Cyclops vicinus } \\
\text { Acanthocyclops robstus }\end{array}$}} \\
\hline \multirow{2}{*}{\multicolumn{10}{|c|}{$\begin{array}{l}\text { Acanthocyclops robstus } \\
\text { Diacyclops bicuspidatus }\end{array}$}} \\
\hline & & & & & & & & & \\
\hline \multicolumn{10}{|c|}{ Mesocyclops ruttneri } \\
\hline Nauplius & 9 & 1.5 & & 9 & 2.1 & 15.5 (Dec-S) & 12 & 1.2 & 6.5 (Apr-M) \\
\hline Copepodid & 9 & 0.6 & 3.1 (May-S) & 10 & 0.6 & $3.9(\mathrm{Apr}-\mathrm{M})$ & 8 & 0.1 & $0.7(\mathrm{Apr}-\mathrm{M})$ \\
\hline
\end{tabular}

*: not identified in species

(S, surface layer, $M$, middle layer, $B$, bottom layer)

Ploesoma truncatum and Synchaeta stylata were found abundantly. Some of these rotifer species indicated different patterns of seasonal changes in density from year to year (Fig. 3, Table 1). For example, Asplanchna priodonta showed density peaks twice in 1993 (September, December), three times in 1994 (April, August and December), and only once in 1995 (October). The highest density, 13.3 individuals $1^{-1}$, was found at the surface layer in December 1994. However, the density peaks of Kellicottia longispina were found in April or May every year with the highest peak in May 1994 (125 individuals $\mathrm{l}^{-1}$ at the middle layer). Seasonal changes in the population density of Ploesoma truncatum differed little from year to year and its density peaks occurred in October or November with the highest density of this species (17.3 individuals $\mathrm{l}^{-1}$ ) was obtained at the surface layer in November 1994. Synchaeta stylata became abundant mainly from January to March every years, but the density was remarkably higher in 1994 (max. 43.7 individuals $1^{-1}$, February, middle layer).

Among crustacean species, Bosmina longirostris, Daphnia galeata, and 


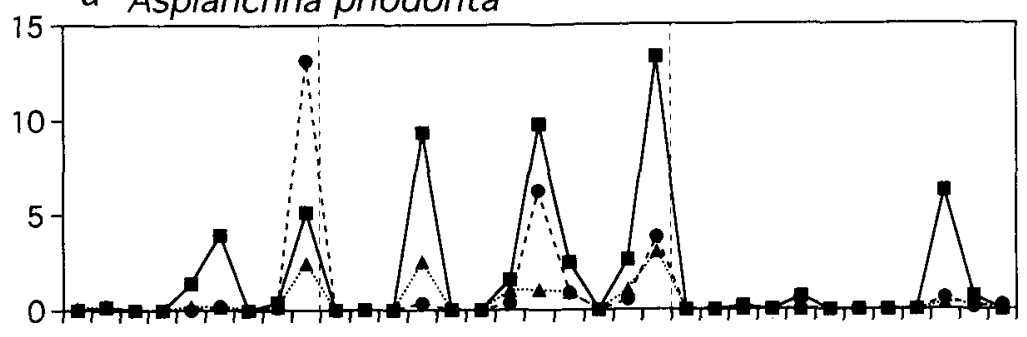

b Kellicottia longispina
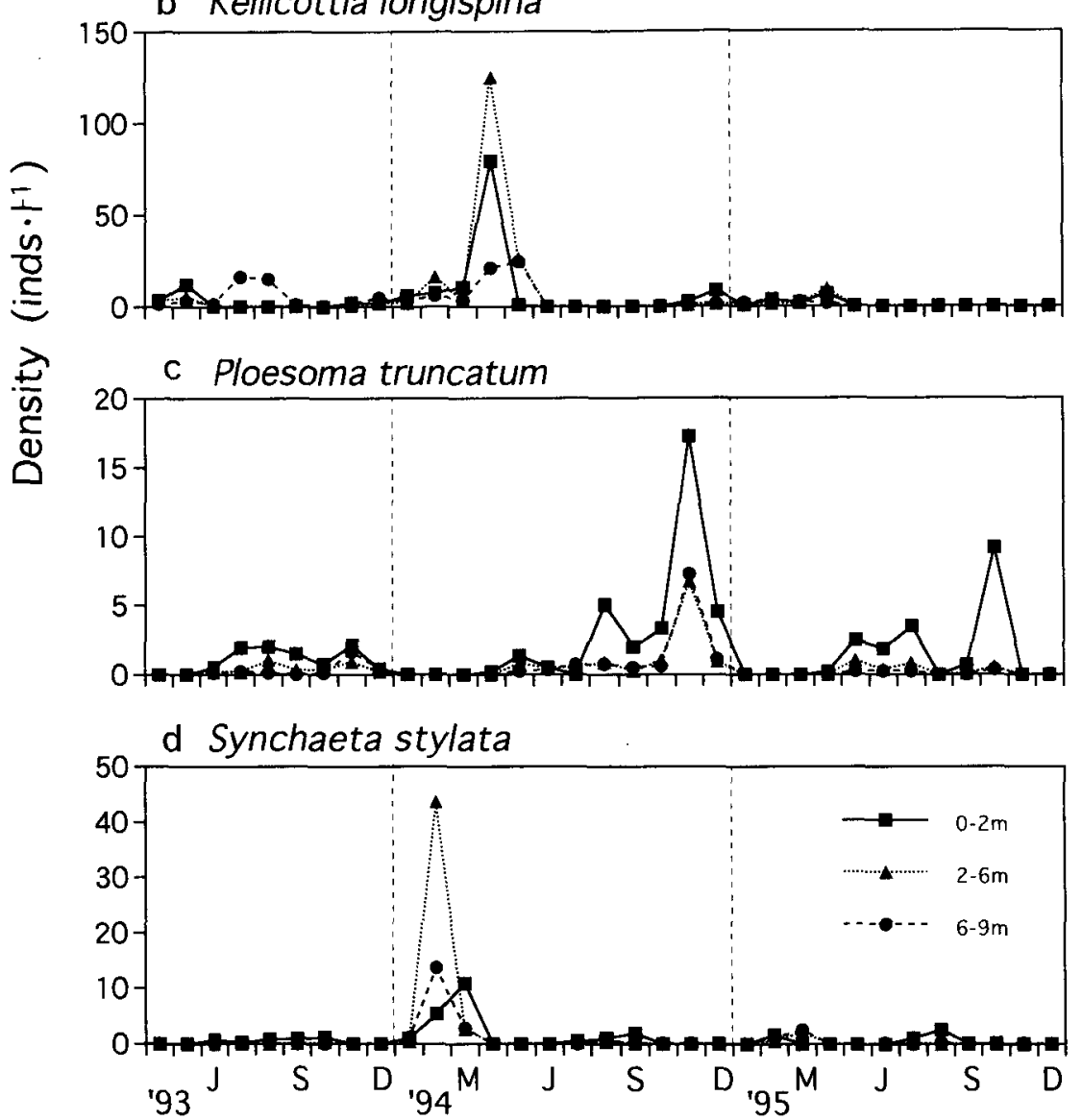

Fig. 3. Seasonal changes and vertical distribution of density (individuals $1^{-1}$ ) of dominant rotifer species (Asplanchna priodonta ${ }^{-a)}$, Kellicottia longispina ${ }^{-b}$, Ploesoma truncatum ${ }^{-\mathrm{c})}$, Synchaeta stylata $^{-\mathrm{d})}$ )

Cyclopidae were also found abundantly (Table 1). Their seasonal changes in density differed little from year to year compared to rotifers (Fig. 3, 4). Bosmina longirostris peaked in density in May and from November to January. The highest density, 20.6 individuals $1^{-1}$, appeared at the surface layer in November 1995. Daphnia galeata were found commonly except in winter (from January to March), with density peaks in May 1993 (max. 


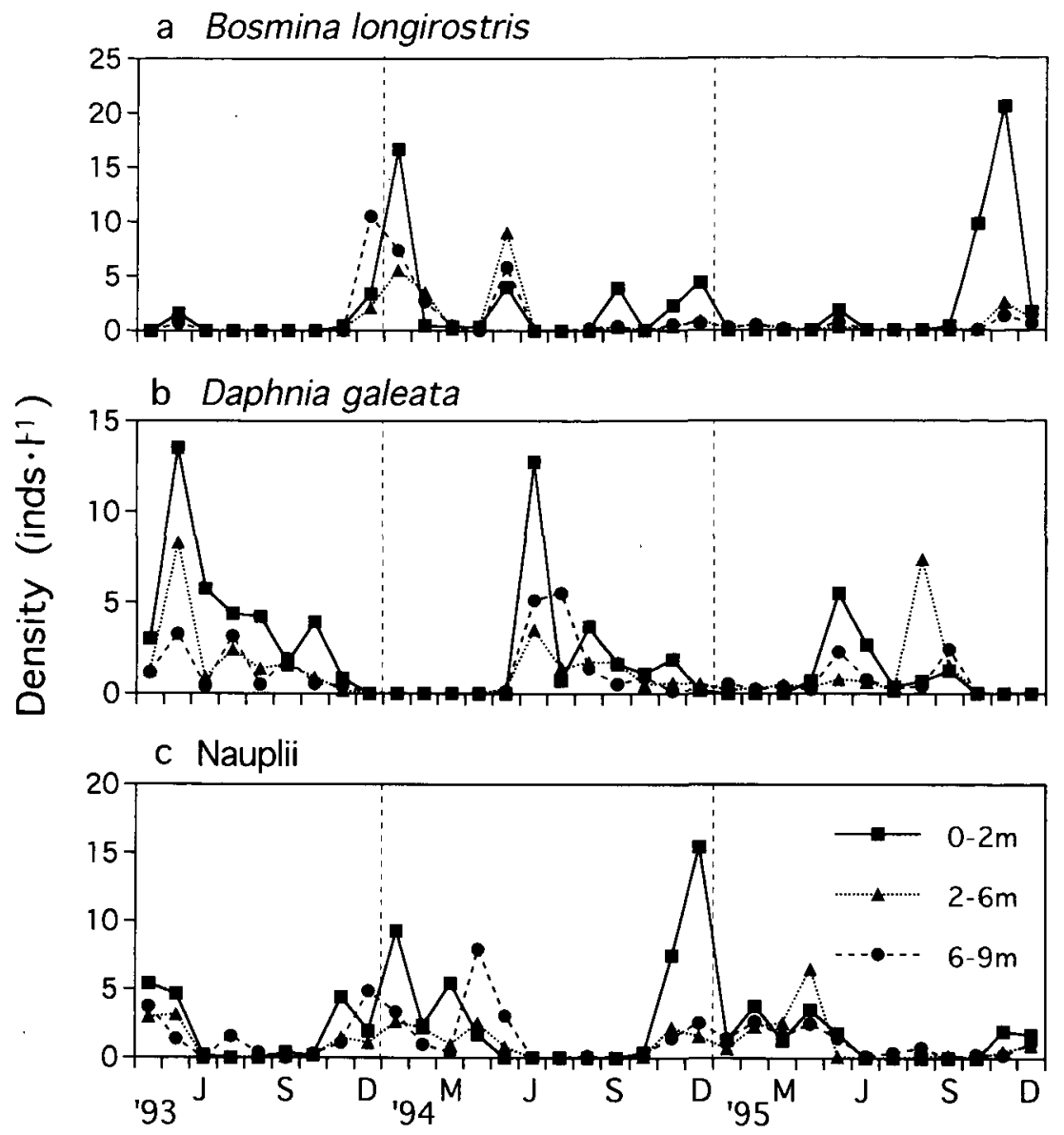

Fig. 4. Seasonal changes and vertical distribution of density (individuals $\mathrm{l}^{-1}$ ) of dominant crustacean species (Bosmina longirostris ${ }^{-a)}$, Daphnia galeata $^{-b}$, Nauplii of Copepoda ${ }^{-c)}$ )

13.5 individuals $1^{-1}$, surface layer), June 1994, and May and August 1995. Four Cyclopoida species, Cyclops vicinus, Acanthocyclops robustus, Diacyclops bicuspidatus, Mesocyclops ruttneri, were identified in the present study. Calanoida species were found only in May 1993 at a low density $(0.2$ individuals $\mathrm{l}^{-1}$, middle layer). Nauplii stages of these species were commonly found although limited individuals of their copepodid stages were collected. In general, the nauplii density was abundant from winter to spring, and the highest density was 15.5 individuals $\mathrm{l}^{-1}$, which was obtained at the surface layer in December 1994.

Several studies have examined zooplankton species composition and their abundance in Lake Kawaguchi (INABA, 1934 ; KADOTA, 1962 ; IWAO, 1971 ; FURUTA et al., 1974 ; TANAKA, 1992). In these studies, zooplankton was sampled only several times a year. In the present study, however, zooplankton samples were collected monthly. Therefore, it is possible to compare 
the present study with the previous studies to examine the changes in zooplankton fauna between the past and the present.

INABA (1934) found Dinobryon most abundantly and Polyarthra, Difflugia and Euglypha commonly in the plankton samples collected from Lake Kawaguchi in February 1934. TANAKA (1992) also reported the common appearance of Dinobryon in October 1986. These reports coincide with the results of the present study, where Dinobryon spp. was found commonly at high densities. However, KADOTA (1962) collected few Dinobryon but many Bosminopsis deitersi in summer 1958. IWAO (1971) also found few Dinobryon but numerous Ploesoma truncatum in June 1968. Similarly, FuruTA et al. (1974) found no Dinobryon and but abundant Ploesoma and Bosmina in all basins in August 1970, and explained the decrease in Dinobryon as due to the progress of eutrophication. However, the results of the present study clearly indicated that the numbers of Dinobryon were lower in summer than in the other seasons, and verified the existence of Ploesoma in summer in the lake (Fig. 3-c). The sampling was conducted in fall or winter by INABA (1934) and TANAKA (1992), and in summer by Kadota (1962), Iwao (1971) and FuruTA et al. (1974). Thus, the difference in the results among previous studies seems to be due to the difference in the sampling season rather than to changes in the lake environment.

In the case of Cladocera, few Daphnia species were collected in previous studies (Table 1, see TANAKA 1992), but Bosmina fatalis were found commonly by KADOTA (1962, identified as Bosmina coregoni) in 1958, FURUTA et al. (1974) in 1970 and TANAKA (1975) in 1972. However, some individuals of Daphnia hyalina but none of Bosmina species were collected by TANAKA (1992) at a later sampling time (October 1986). TANAKA (1992) thus suggested that Daphnia have appeared and Bosmina fatalis have been decreasing in recent years. In the present study, Daphnia galeata were found commonly but Bosmina fatalis were not found. These results suggest that Daphnia galeata have been increasing and Bosmina fatalis had disappered after the 1980s.

HANAZATO et al. (1984) and HANAZATO and YASUNO (1987) suggest that the occurrences of Bosmina fatalis are related to the occurrence of Microcystis bloom. In Lake Kawaguchi, Microcystis aeruginosa was abundant in the 1970s (IWAO, 1971 ; FuruTA et al., 1974). However, it has not bloomed in recent years (ARAKAWA, personal observation), probably because the lake water quality has been restored by some steps taken against eutrophication such as constructing a sewage treatment plant (SHIMIzU et al., 1990). Thus, the recent decrease in Bosmina fatalis may be related to changes in the water quality. Bosminopsis deitersi were also found commonly in previous studies (KADOTA, 1962 ; IwAO, 1971 ; FuRUTA et al., 1974), but could not be found in this study. This species also seemed to have decreased or vanished in recent years.

The present study shows that the zooplankton community structure has changed remarkably in recent years. Because zooplankton is situated at the mid-point of the food web, changes in the structure and biomass of a 
zooplankton community would be mirrored by similar changes in the other biological components in lake ecosystems through biological interactions. Thus, further analyses should be undertaken to clarify the cause and effects of changes in the zooplankton community of Lake Kawaguchi.

\section{ACKNOWLEDGEMENTS}

We wish to thank the Tozawa Leisure Center for its support of our field survey, as well as Mr. M. Tsutsumi, Dr. S. ToBiTA and Mr. M. HorIuCHI of Yamanashi Institute of Public Health for their analyses of lake water samples. Thanks are also due to Dr. T. IsHIDA who identified Copepoda species. We are grateful to Prof. T. Hanazato and Prof. T. Okino, Faculty of Science, Shinshu University for their helpful suggestions, discussion and critical reading of the manuscript. This study was partly supported by a grant from the Zenrosai Foundation.

\section{REFERENCES}

Brooks, J. L and S. I. Dodson (1965) : Predation, bodysize and composition of plankton. Science, $150: 28-35$.

Furuta, Y., M. Suginome and M. Tanaka (1974) : On the fauna and flora in Lake Kawaguchi in summer. Bull. Freshwat. Fish. Res. Lab., 24: 1-9. (in Japanese with English abstract)

Hanazato, T., M. Yasuno, T. Iwakuma and N. Takamura (1984) : Seasonal changes in the occurrence of Bosmina longirostris and Bosmina fatalis in relation to Microcystis bloom in Lake Kasumigaura. Jpn. J. Limnol., 45 : 153 $-157$.

Hanazato, T. and M. Yasuno (1987) : Experimental studies on competition between Bosmina longirostris and Bosmina fatalis. Hydrobiologia, 154 :189 -199 .

InABA, D. (1934) : Five Lakes of Mt. Fuji in winter, 1934. Jpn. J. Limnol., 4 : 101-114 (in Japanese).

Iwao, Y. (1971) : The report of limnological study in Lake Kawaguchi. Biol. Inland Wat., $4: 1-3$ (in Japanese).

KadotA, S. (1962) : On the plankton in Lake Kawaguchi in summer, 1958. Bull. Coll. Agr. \& Vet. Med., Nihon Univ., 15 : 54-61 (in Japanese).

Shimizu, G., H. Ohkubo, T. Takahashi and M. Tsutsumi (1990) : Water quality of Lake Kawaguchi in 1980-1989. Ann. Rep. Yamanashi Inst. Publ. Health, $34: 52-55$ (in Japanese).

Takahashi, K., T. KirYu, T. OKazaki and H. Ohama (1995) : Ecological study of Hypomesus transpacificus nipponnensis. Rep. Yamanashi Pref. Fish. Technol. Center $23: 54^{-92}$ (in Japanese).

TANAKA, M. (1975) : Studies on the genus Bosmina of japan-I. Notes on the geographical distribution of Bosmina fatalis BurckHARDT. Bull. Biogeogr. Soc. Jap., $30: 35-41$ (in Japanese with English abstract).

TanaKa, M. (1992) : The lakes in Japan. p. 344-348, Nagoya Univ. Publ. (in Japanese) . 
UNESCO (1966) : Determination of photosynthetic pigments in seawater. UNES$\mathrm{CO}$, Paris.

Takashi AraKawA : Saku-Chosei Highschool, 951 Iwamurada, Saku, Nagano, 385 -0022 (荒河 尚：干 385-0022 長野県佐久市岩村田 951, 佐久長聖高等学校)

Norihiko YoshIDA : Department of Human Life Studies, Yamanashi Women's College, 5-11-1 Iida, Kofu, Yamanashi, 400-0035 (吉田雅彦： ₹ 400-0035 山梨県甲府市飯田 5-11-1, 山梨紫立女子短期大学)

Kimio Hirabayashi : Liveral Arts, Yamanashi Women's College, 5-11-1 Iida, Kofu，Yamanashi，400-0035 (平林公男：=400-0035 山梨県甲府市飯田 5 -11-1, 山梨県立女子短期大学)

Kazuya Yoshizawa : Yamanashi Institute for Public Health, 1-7-31 Fujimi, Kofu, Yamanashi, 400-0027 (吉澤一家： T 400-0027 山梨県甲府市富士見 1-7-31, 山梨県衛生公害研究所)

(Received 11 January 1997 ; Accepted : 3 October 1997)

\section{河口湖における動物プランクトン群集構造の経年的 および季節的变動}

荒河 尚・吉田雅彦・平林公男・吉澤一家

摘要

河口湖における動物プランクトン群集の経年的および季節的変動を, 1993 年 4 月より 1995 年 12 月にかけて調查した。期問中輪虫類が 16 分類群, 枝角類が 4 分類群, カイアシ 類が 5 分類群確認され，なかでも Kellicottia longispina, Synchaeta stylata, Bosmina longirostris, Daphnia galeataなどが多くみられた。また，カイアシ類はそのほとんどが Cyclopoida に分類された。さらに過去の報文との比較において，枝角類 Bosmina fatalis， Bosminopsis deitersiが近年見られなくなっていることが明らかになり, 近年本湖の動物プ ランクトン群集構造が大きく変わってきていることが示された。 